\title{
DRIP PULSES AND SOIL MULCHING EFFECT ON AMERICAN CRISPHEAD LETTUCE YIELD
}

Doi:http://dx.doi.org/10.1590/1809-4430-Eng.Agric.v35n6p 1009-1018/2015

\section{WILLIAN F. DE ALMEIDA ${ }^{1}$, LUIZ A. LIMA ${ }^{2}$, GERALDO M. PEREIRA ${ }^{3}$}

\begin{abstract}
An experiment was conducted in a greenhouse at the Federal University of Lavras cultivated with American lettuce, cv. Raider-Plus. The aim of this study was to evaluate the effects of irrigation water depths applied by drip pulses and of soil coverage on crop yields and efficiency of water use. The experimental design used was randomized blocks with eight treatments and three replications, totaling twenty-four plots. The treatments consisted of soil with and without coverage (double-sided white and black plastic) associated with four irrigation management levels. Irrigation management consisted in reposition of irrigation depths based on crop evapotranspiration $\left(\mathrm{ET}_{\mathrm{c}}\right)$ with $\mathrm{D}_{1}-100 \%$ of $\mathrm{ET}_{\mathrm{c}}$, applied continuously (control), and $\mathrm{D}_{2}-100 \%$ of $\mathrm{ET}_{\mathrm{c}}, \mathrm{D}_{3}-75 \%$ of $\mathrm{ET}_{\mathrm{c}}$, and $\mathrm{D}_{4}-50 \%$ of $\mathrm{ET}_{\mathrm{c}}$, applied by pulses. Irrigation by pulses consisted in splitting the depths into six irrigation pulses with intervals of fifty minutes of rest. It was observed that pulse irrigation saved $25 \%$ of water in treatment without mulching and $50 \%$ when plastic mulching was used, contributing substantially to improve irrigation water efficiency.
\end{abstract}

KEYWORDS: water-use efficiency, greenhouse, water depth.

\section{GOTEJAMENTO POR PULSOS E COBERTURA DO SOLO NA PRODUTIVIDADE DA ALFACE-AMERICANA}

\begin{abstract}
RESUMO: Um experimento foi conduzido em ambiente protegido, na Universidade Federal de Lavras, com a cultura da alface-americana cv. Raider-Plus. O objetivo do trabalho foi avaliar os efeitos de lâminas de irrigação aplicadas via gotejamento por pulsos e da cobertura do solo sobre a produtividade e a eficiência do uso da água. O delineamento experimental foi o de blocos ao acaso, em que foram utilizados oito tratamentos e três repetições, perfazendo um total de vinte e quatro parcelas experimentais. Os tratamentos constituíram-se do solo com e sem cobertura (plástico dupla face branco/preto), associado a quatro manejos de irrigação. Os manejos de irrigação consistiram na reposição de lâminas de irrigação, com base na evapotranspiração da cultura $\left(\mathrm{ET}_{\mathrm{c}}\right)$, sendo $\mathrm{L1}$; $100 \%$ da ETc, aplicada de forma contínua (testemunha), e L2; 100\% da ETc, L3; 75\% da ETc e L4; $50 \%$ da ETc, aplicadas por pulsos. A irrigação por pulsos consistiu no parcelamento da lâmina, em seis pulsos de irrigação, com intervalos de cinquenta minutos de repouso. Foi observado que o gotejamento por pulsos proporcionou a economia de $25 \%$ de água no tratamento sem cobertura plástica e a economia de $50 \%$ de água no tratamento com cobertura plástica do solo, o que resultou no aumento da eficiência do uso da água.
\end{abstract}

PALAVRAS-CHAVE: eficiência do uso da água, ambiente protegido, lâminas de irrigação.

\section{INTRODUCTION}

Farming techniques that increase yield and quality with rational use of natural resources have become more popular. This is the main objective of modern agriculture, which is increasingly

\footnotetext{
${ }^{1}$ Tecg $^{\circ}$ Recursos Hídricos/Irrigação, Doutor em En genharia A grícola, DEG/UFLA, Pós-doutorando (PNPD/CAPES), Núcleo de Engenharia de Á gua e Solo, Universidade Federal do Recôncavo da Bahia, CEP 44380-000, Cruz das Almas, BA, Fone: (75) 99201-4189,wifatec@y ahoo.com.br.

${ }^{2}$ Eng $^{\circ}$ A grícola, Ph.D. Prof. Associado do Departamento de Engenharia, Universidade Federal de Lavras, Campus Universitário, Caixa Postal 3037, CEP 37200-000, Lavras (MG), Brasil, lalima@deg.ufla.br

${ }^{3}$ Eng $^{\circ}$ A grícola, Prof. Doutor, Departamento de Engenharia Agrícola, Universidade Federal de Lavras, Campus Universitário, Caixa Postal 3037, CEP 37200-000, Lavras (MG), Brasil, geraldop @ufla.br 
focused on investing in new technologies to enhance yield, reduce costs, and sustainably improve the quality of products.

Recently, the irrigation by pulses technique has been studied, which consists in practice of a short period of irrigation, followed by a resting phase and another short irrigation period; this cycle is repeated until the irrigation depth is completely applied.

Pulse drip irrigation has been tested on several crops around the world, such as on pepper in Israel (ASSOULINE et al., 2006), on corn in Egypt (ZIN EL-ABEDIN, 2006), on tomato in the United States (WARNER; HOFFMAN; WILHOIT, 2009), and on potato in Egypt (ABDELRAOUF et al., 2012; BAKEER et al., 2009). These studies investigated positive impacts on yield, improvements in product quality, savings in water use, reductions in emitter obstruction, etc.

Another technique of great contribution to food production is the covering of soil with plastic material (mulching); a method that aims to control weeds and reduce water loss through evaporation. It also facilitates harvesting and commercialization, as the end product is healthier and cleaner. However, when covering the soil, important parameters of microclimate are altered, such as soil temperature and this influences water evaporation and microorganisms growth - factors that directly affect water consumption, as well as crop growth and development (GONÇALVES; FAGNANI; PERES, 2005). The mulching has become more widespread in recent years, mainly in the cultivation of several vegetables, such as American crisphead lettuce.

Crisphead lettuce has been acquiring greater importance, mostly in the South region of Minas Gerais (RESENDE et al., 2009). This cultivar is characterized by a compact head and is ideal for the fast food market segment. It also possesses thick and crunchy leaves, as well as greater postharvest durability (SALA; COSTA, 2012).

Lettuce production goes through periods of unfavorable meteorological conditions at times of the year. One of the existing alternatives to minimize the effect of agro climatic adversity is greenhouse cultivation. This technique aims to obtain greater yield, with improved quality of final product throughout the year, by offering effective protection from climate events, such as frost, excessive rainfall, and decreased night temperature. It also protects soils from leaching, reduces fertilization and pesticide costs, and hinders possible infestations by pests and diseases that could increase crop production costs and eventually cause damage to the environment.

Lettuce is a crop that demands high levels of water and when cultivated in a greenhouse, irrigation is indispensable and the only way to replace the water consumed by the plant.

Considering the lettuce water requirements and the benefits reported through studies about pulse drip irrigation and soil coverage, this study aimed at evaluating the effects of irrigation water depths applied via drip irrigation, with and without mulching, on yields of greenhouse grown crisphead lettuce, as well as on system water-use efficiency.

\section{MATERIAL AND METHODS}

The experiment was conducted in a greenhouse (arc model), covered with transparent plastic film of $0.15 \mathrm{~mm}$ thickness. This structure was installed at an experimental area belonging to the Engineering Department of the Federal University of Lavras (UFLA), from May to July 2011. This area is located at $21^{\circ} 13^{\prime} 48^{\prime \prime}$ of south latitude, $44^{\circ} 58^{\prime} 36^{\prime \prime}$ west longitude, and at an altitude of 902 m.

According to Köppen classification, the region presents $\mathrm{C} w a$ climate, in other words, rainy mild climate (mesothermal), with dry winter and rainy summer, average temperature of the coldest month bellow $18{ }^{\circ} \mathrm{C}$ and above $3{ }^{\circ} \mathrm{C}$; and summer presents average temperature of the hottest month above $22^{\circ} \mathrm{C}$ (DANTAS; CARVALHO; FERREIRA, 2007).

Meteorological data from inside the greenhouse were obtained through a portable and automatic agro meteorological station, DAVIS brand, VANTAGE PRO 2 model, installed in the 
greenhouse center ( $2 \mathrm{~m}$ of height), with constant monitoring of temperature, and air relative humidity.

The soil from experimental area was classified as dystroferric Red Latosol, of which sieve analysis indicated average values of $68 \mathrm{dag} \mathrm{kg}$ of clay, $22 \mathrm{dag} \mathrm{kg}^{-1}$ of silt, and $10 \mathrm{dag} \mathrm{kg} \mathrm{gf} \mathrm{sand}^{-1}$ soil density of $0.98 \mathrm{~kg} . \mathrm{dm}^{-3}$, and particle density of $2.84 \mathrm{~kg} . \mathrm{dm}^{-3}$. Soil moisture at field capacity ($10 \mathrm{kPa}$ ) was of $0.361 \mathrm{~cm}^{3} \mathrm{~cm}^{-3}$, and permanent withering point was of $0.217 \mathrm{~cm}^{3} \mathrm{~cm}^{-3}$. Soil chemical analysis was carried out in the soil laboratory of the Department of Soil Science (DCSUFLA), after sampling made in the experimental area, before initial soil preparation, at depth of 0.0 to $0.30 \mathrm{~m}$ (Table 1).

TABLE 1. Chemical characteristics of soil before fertilization.

\begin{tabular}{|c|c|c|c|c|c|c|c|c|c|c|c|c|c|}
\hline $\begin{array}{l}\text { oH M.O. } \\
\mathrm{g} \mathrm{dm}^{-3}\end{array}$ & $\begin{array}{c}\mathrm{P} \\
\mathrm{mg} \mathrm{dm^{-3 }}\end{array}$ & $\mathrm{Ca}$ & $\begin{array}{l}\mathrm{Mg} \\
--\mathrm{m}\end{array}$ & $\begin{array}{l}\mathrm{H}+\mathrm{Al} \\
\mathrm{nol}_{\mathrm{c}} \mathrm{dm}^{-}\end{array}$ & & CTC & $\begin{array}{l}\mathrm{V} \\
\%\end{array}$ & $\mathrm{~K}$ & B & $\begin{array}{l}\mathrm{Cu} \\
-\mathrm{mg} \mathrm{dn}\end{array}$ & $\underset{n^{-3}-\cdots}{\mathrm{Fe}}$ & $\mathrm{M}$ & $\mathrm{Zn}$ \\
\hline $\begin{array}{ll}6.8 & 26.1 \\
\end{array}$ & 11.88 & 38.3 & 5.4 & 14.8 & 14 & 31 & 45.9 & 98 & 0.1 & 8.5 & 59 & 5 & 0.3 \\
\hline
\end{tabular}

The area was prepared with one plowing and one harrowing, in sequence, seedbeds with 1.2 $\mathrm{m}$ of width, $1.50 \mathrm{~m}$ of length, and $0.15 \mathrm{~m}$ of height, were constructed with the aid of a hoe. In this occasion, phosphor fertilizer was incorporated to the soil (100 kg/ ha of P), following recommendations from the Soil Fertility Commission of Minas Gerais State: fifth Approximation (GOMES; SILVA; FAQUIN, 1999). The same guide was also basis for fertilization which accounted for $150 \mathrm{Kg} /$ ha of $\mathrm{N}, 60 \mathrm{~kg} /$ ha of $\mathrm{K}_{2} \mathrm{O}, 3 \mathrm{~kg} /$ ha of $\mathrm{Zn}$ and $1 \mathrm{~kg} / \mathrm{ha}$ of $\mathrm{B}$.

The double-sided black and white mulching was placed on seedbeds one day before treatment initiation, face installed downwards, in contact with the soil.

We used the Raider-Plus cultivar of American crisphead lettuce of Seminis Vegetable Seeds, Inc. This breeding line is characterized for presenting an 85-day cycle, big-sized and compact plants with tougher leaves of light green coloration. It is indicated for winter cultivation and ideal for fresh markets and processing.

Seeding was carried out on April $16^{\text {th }}, 2011$, in 200-cell polystyrene trays filled with commercial substrate (Plantmax HT, Eucatex). Two sprays with pyrethroid insecticide (Karate ${ }^{\circledR}-40$ $\mathrm{g} / \mathrm{hl}$ ) and copper oxychloride-based fungicide (Melody Cobre ${ }^{\circledR}-150 \mathrm{~g} / \mathrm{hl}$ ) were carried out. Seedlings were accompanied in greenhouse during 25 days, and were manually transplanted on May $10^{\text {th }}, 2011$ to seedbeds previously dampened. The seedlings were spaced in $0.30 \times 0.30 \mathrm{~m}$, with bed spacing of $0.25 \mathrm{~m}$, totaling 78,660 plants per hectare.

Before transplanting, the soil was irrigated until reaching field capacity; and during the 7-day seedling acclimatization period, water applications corresponding to $100 \%$ of ETc were carried out, being estimated based on readings from mini-tank evaporimeter installed inside the greenhouse.

A drip irrigation system was installed with inline pressure-compensating emitters, which consist of emitters inserted in the hose during extrusion process. We used nozzles of NAAN PC model with nominal flow of $1.6 \mathrm{~L} \mathrm{~h}^{-1}$ and distant $0.30 \mathrm{~m}$ from each other. The drip tape (DN 16 $\mathrm{mm}$ ) was placed in the plot in order to assist two plant lines, working with operating pressure of around $140 \mathrm{kPa}$, which was controlled through a pressure-regulating valve inserted in the control head, before electrical command valves (solenoids). One valve was used for each treatment; such valves were activated through a Programmable Logic Controller (RAIN BIRD), previously programmed, in each irrigation, to work for as long as necessary aiming to replace the required demand to fill water depth.

The beds $(1.5 \times 1.2 \mathrm{~m})$ were irrigated by two sidelines of dripping, parallel to the greatest length, spaced in $0.60 \mathrm{~m}$ between each other and $0.30 \mathrm{~m}$ between drippers, totaling 10 application points per plot (Figure 1). 

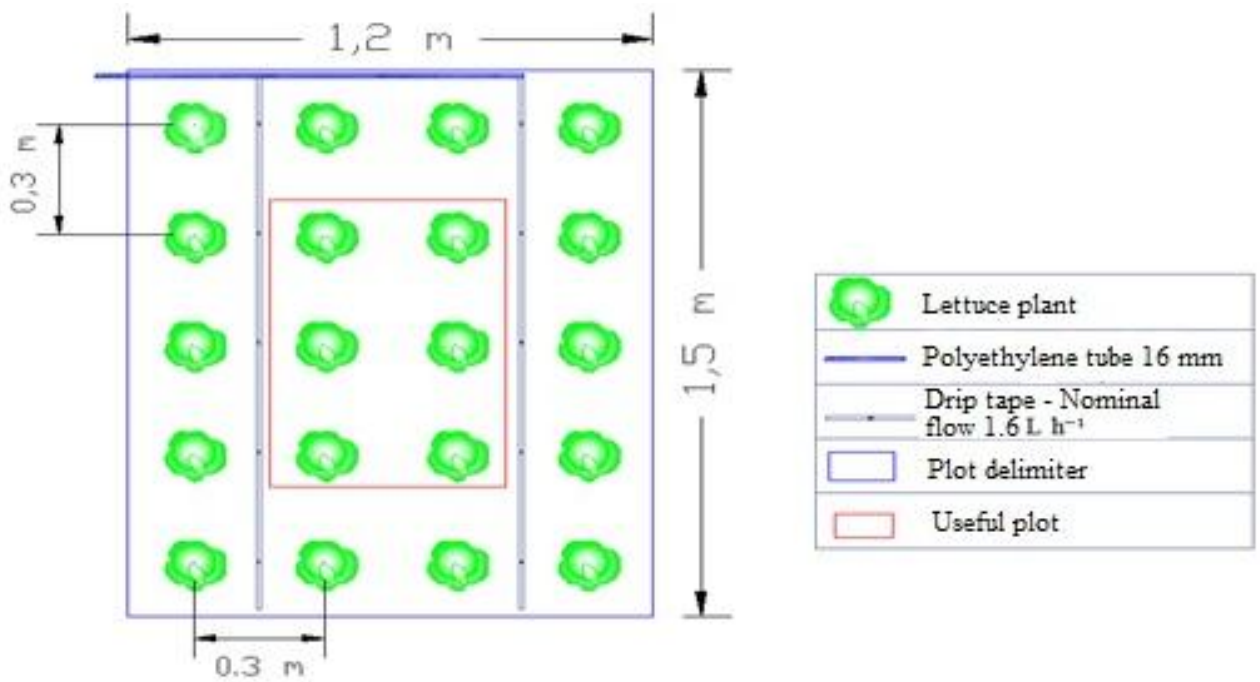

FIGURE 1. Experimental plot with irrigation system.

Tests were conducted to determine dripper average flow and distribution uniformity coefficient (DUC). The DUC was proposed by Keller \& Karmeli (1975) and compares the average of $25 \%$ of the lowest observed flow values with the flow total average to determine water application uniformity of irrigation systems by dripping. Values of $1.86 \mathrm{~L} \mathrm{~h}^{-1}$ for flow and 0.99 for DUC were found, indicating high water distribution uniformity within the plots.

The adopted experimental designed was randomized blocks (RBD), in factorial scheme $(2 \times 3$ $+2) \times 3$ (coverage $x$ pulse drip irrigation + two controls) with three replications, using eight treatments in total, and totaling 24 plots. The controls consisted in reposition of $100 \%$ of ETc, applied through continuous dripping, one with and another without plastic coverage. Each experimental plot was composed of four plant lines spaced $0.30 \mathrm{~m}$ between lines and $0.30 \mathrm{~m}$ between plants, in a total of 20 plants per plot (Figure 1).

The treatments consisted of soil with and without mulching (double-sided black and white plastic) associated with four irrigation management levels. The irrigation management levels consisted in reposition of irrigation water depths (ID), based on crop evapotranspiration (ETc), with D1 - 100\% of ETc applied continuously (control) and D2 - 100\% of ET, D3 - 75\% of ETc and D4 $50 \%$ of ETc, applied by pulses. Pulse irrigation involved splitting ID into six irrigation pulses with intervals of fifty minutes (irrigation/ rest). Pulses started at 9 am and had enough duration to apply one sixth of programmed water depth. An electronic controller and solenoid valves controlled irrigation times.

The applied water depth, with irrigation schedule of two days, was calculated in accordance with [eq. (1)]. An evaporation mini-tank was used (minimized class A tank) for evaporation estimation. The mini-tank Kp adopted value was 1 , which was also adopted by BANDEIRA et al. (2011). The adopted Kc (0.60, 0.8, 1.05 and 1.0) was recommended by MAROUELLI, SILVA and SILVA (1996).

$$
N I D=\frac{E V m \cdot K p \cdot K c}{E a}
$$

In which,

$\mathrm{NID}=$ necessary irrigation depth, $\mathrm{mm}$;

$\mathrm{EV}_{\mathrm{m}}=$ mini-tank evaporation measured within the period, mm;

$\mathrm{K}_{\mathrm{c}}=$ crop coefficient;

$\mathrm{K}_{\mathrm{p}}=$ tank coefficient,

$E_{a}=$ water application efficiency of the adopted irrigation system (0.95). 
Different water depths were obtained for each treatment regarding different functioning times of dripping lines. This time was obtained through [eq. (2)].

$$
T i=\frac{L I N . s p . s l p}{e . q}
$$

In which,

$$
\begin{aligned}
& \mathrm{Ti} \text { = irrigation time for each treatment, } \mathrm{h} \\
& \mathrm{sp}=\text { spacing between plants, } 0.30 \mathrm{~m} ; \\
& \mathrm{slp}=\text { spacing between plant lines, } 0.30 \mathrm{~m} ; \\
& \mathrm{e}=\text { number of emitters per plant }(0.5), \\
& \mathrm{q}=\text { average flow of dripper, } 1.86 \mathrm{~L} \mathrm{~h}^{-1}
\end{aligned}
$$

Top dressings were divided into three applications (15, 30, and 45 days after transplanting), spreading a total of $280 \mathrm{~g}$ of $\mathrm{K}_{2} \mathrm{O}$ and $560 \mathrm{~g}$ of $\mathrm{N}$ over the total area (plots). These doses were applied in solution form with the aid of a syringe, precisely on soil around the dripper, using potassium chloride and calcium nitrate as nutrient sources.

Aiming to prevent nutritional deficits, which could arise during crop development, three foliar fertilizations were carried (Nitrofoska $A$ ) during the whole lettuce cycle (12, 28, and 37 days after transplanting). This fertilizer presents in its formulation the following nutrient concentration: $10 \%$ of $\mathrm{N}, 4 \%$ of $\mathrm{P}_{2} \mathrm{O}_{5}, 7 \%$ of $\mathrm{K}_{2} \mathrm{O}, 0.02 \%$ of $\mathrm{B}, 0.05 \%$ of $\mathrm{Cu}$ and $0.02 \%$ of $\mathrm{Mn}$.

Regarding plant health, two sprays with pyrethroid insecticides and copper oxychloride-based fungicide were conducted during the experimental period. Weeds found were manually removed from treatments without soil coverage.

In this study, total yield and commercial head yield were evaluated, (obtained after removing external leaves with yellowish coloration and/ or burn edges), as well as the water-use efficiency for each treatment (relation between yield and total volume of water used in production). For this purpose, on July $10^{\text {th }} 2011$, six plants of each experimental plot were harvested, totaling 18 plants per treatment.

After harvesting, the plants were weighted, and in sequence taken to a forced ventilation oven at $65^{\circ} \mathrm{C}$ during $72 \mathrm{~h}$, to achieve constant mass. Fresh and dry mass were determined using a scale of $0.01 \mathrm{~g}$ precision.

The experimental data were submitted to variance analysis (ANOVA). When considered significant by the $\mathrm{F}$ test, means were compared by the Tukey test at $5 \%$ of probability, aiming to verify existence of any significant difference among treatments. All the statistical analysis was conducted with the aid of SISVAR statistical software, 4.6 version (FERREIRA, 2003).

The water-use efficiencies (WUE) of American crisphead lettuce crop, in planting systems with and without soil coverage, were obtained in $\mathrm{kg}$ of lettuce fresh mass per $\mathrm{m}^{3}$ of water applied through irrigation.

\section{RESULTS AND DISCUSSION}

Air relative humidity and temperature variations during experiment are shown in Figure 2. It is observed that air average humidity and temperature were $65.3 \%$ and $18.3{ }^{\circ} \mathrm{C}$, respectively. These average values of temperature were considered adequate for lettuce growth $\left(15\right.$ and $\left.20{ }^{\circ} \mathrm{C}\right)$, according to SANTANA, ALMEIDA AND TURCO (2009). 

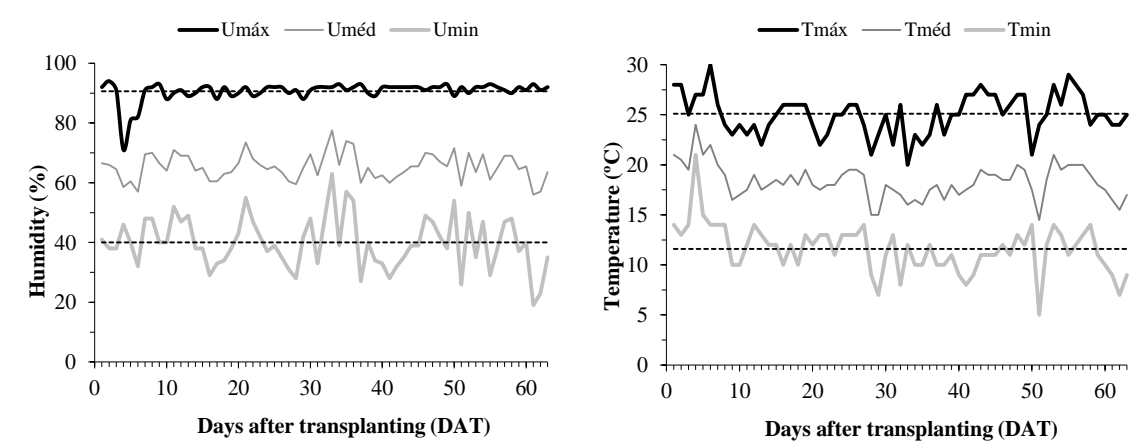

FIGURE 2. Maximum, minimum and average values of air relative humidity and of air temperature inside the greenhouse.

Table 1 displays accumulated values of irrigation water depths applied for different percentages of studied ETc, during experimental period.

TABLE 1. Irrigation water depths ( $\mathrm{mm}$ ) in American crisphead lettuce, cv. Raider-Plus, cultivated in greenhouse and irrigated through pulse and continuous drip irrigation, with and without mulching.

\begin{tabular}{cccc}
\hline $\begin{array}{c}\text { Treatment } \\
(\% \text { ETc })\end{array}$ & $\begin{array}{c}\text { Initial depth } \\
(\mathrm{mm})\end{array}$ & Differentiated depth $(\mathrm{mm})$ & $\begin{array}{c}\text { Total Depth } \\
(\mathrm{mm})\end{array}$ \\
\hline 100-continuous & 24 & 127.32 & 151.32 \\
100-pulses & 24 & 127.32 & 151.32 \\
75-pulses & 24 & 95.49 & 119.49 \\
50-pulses & 24 & 63.66 & 87.66 \\
\hline
\end{tabular}

The variance analysis (Table 2) identified that there was no significant difference among blocks; however, there was significant effect at $1 \%$ of probability in all applied depths, for mulching and for depth $\mathrm{x}$ mulching interaction. The non-significant effect among blocks may be due to soil and climate heterogeneity inside the greenhouse.

TABLE 2. Variance analysis summary for commercial yield (CY) and total yield (TY) of American crisphead lettuce grown with or without plastic mulching, and under effect of different water depths via pulse and continuous drip irrigation.

\begin{tabular}{lccc}
\hline \multirow{2}{*}{ Variation cause } & \multirow{2}{*}{ DF } & \multicolumn{2}{c}{ Average Square } \\
\cline { 3 - 4 } & & CY & TY \\
\hline Blocks & 2 & $0.16^{\mathrm{ns}}$ & $3.72^{\mathrm{ns}}$ \\
Depths (L) & 3 & $38.29^{* *}$ & $50.02^{* *}$ \\
Coverage (C) & 1 & $499.05^{* *}$ & $704.49^{* *}$ \\
L x C & 3 & $81.66^{* *}$ & $140.97^{* *}$ \\
Residue & 14 & 3.26 & 6.23 \\
CV $(\%)$ & & 6.14 & 5.43 \\
General Average & & 32.03 & 46.03 \\
\hline
\end{tabular}

Significant at $1 \%\left({ }^{(*)}\right)$ of probability; $\left({ }^{\mathrm{ns}}\right)$ not significant by $\mathrm{F}$ test

Table 3 represents the comparison between averages of commercial and total yields of crisphead lettuce for different irrigation and coverage treatments, according to the Tukey test, at 5\% of probability $(\mathrm{p}<0.05)$. 
TABLE 3. Commercial and total yield averages of crisphead lettuce regarding interaction between factors (coverage $\mathrm{x}$ irrigation).

\begin{tabular}{|c|c|c|c|c|}
\hline \multirow{2}{*}{$\begin{array}{c}\text { Treatments } \\
\left(\% \mathrm{ET}_{\mathrm{C}}\right)\end{array}$} & \multicolumn{2}{|c|}{$\begin{array}{l}\text { Commercial Yield } \\
\left(\mathrm{Mg} \mathrm{ha}^{-1}\right)\end{array}$} & \multicolumn{2}{|c|}{$\begin{array}{l}\text { Total Yield } \\
\left(\mathrm{Mg} \mathrm{ha}^{-1}\right)\end{array}$} \\
\hline & Without coverage & With coverage & Without coverage & With coverage \\
\hline 50-Pulses & $19.47 \mathrm{Bb}$ & $38.91 \mathrm{Aa}$ & $30.04 \mathrm{Bb}$ & $54.44 \mathrm{Aa}$ \\
\hline 75-Pulses & $31.52 \mathrm{Ab}$ & $38.71 \mathrm{Aa}$ & $44.75 \mathrm{Ab}$ & $53.78 \mathrm{Aa}$ \\
\hline 100-Pulses & $28.14 \mathrm{Ab}$ & $36.45 \mathrm{Aba}$ & $42.16 \mathrm{Aa}$ & $50.71 \mathrm{ABb}$ \\
\hline 100-Continuous & $30.74 \mathrm{Aa}$ & $32.28 \mathrm{Ba}$ & $45.50 \mathrm{Aa}$ & $46.87 \mathrm{Ba}$ \\
\hline
\end{tabular}

*Averages followed by the same letter do not differ statistically among themselves, upper casein column and lower case in line, by the Tukey test at $5 \%$ of probability.

In treatments without mulching, there was no significant difference of commercial and total yields among treatments for water depth of $100 \%$ of $\mathrm{ET}_{\mathrm{c}}$ through continuous dripping, as well as treatments in which $100 \%$ and $75 \%$ of $\mathrm{ET}_{\mathrm{c}}$ was applied by pulses. It means that, drip irrigation by pulses, in spite of not incrementing yield, assisted in saving $25 \%$ of water without affecting crop yield. Similar results were obtained by ABDELRAOUF et al. (2012) and BAKEER et al. (2009), when comparing continuous dripping with dripping by pulses in potato crop. These authors reported that pulse drip irrigation also enabled savings of $25 \%$ of irrigation necessity.

The treatment in which $50 \%$ of $\mathrm{ET}_{\mathrm{c}}$ was applied without coverage was the one that had worst performance and statistically differed from the others, showing that the water replacement in this treatment was not enough to attend lettuce hydric demands.

Regarding yields obtained by using soil coverage (Table 3), it is verified that greater commercial and total values ( 38.91 and $54.44 \mathrm{Mg} \mathrm{ha}^{-1}$ ) were achieved by the treatment with $50 \%$ of depth applied through drip irrigation by pulses. This treatment did not differ statistically from treatments where 75 and $100 \%$ of depth was applied through dripping by pulses; however, it differed from that in which $100 \%$ of depth was applied through continuous dripping. It is concluded that the interaction between pulse drip irrigation and mulching enabled 50\% of water savings.

It is also highlighted that, except from treatment using continuous drip, the use of plastic mulching increased yield if compared to uncovered soil, reinforcing that the interaction of pulse drip irrigation and mulching favors not only yield, but also promote water savings.

Increased yields promoted by soil covering is related to factors like greater weed and soil temperature control, water evaporation reduction, aside from lower leaching and nitrate volatilization (ALMEIDA et al., 2009; ZRIBI; FACI; ARAGÜES, 2011). In general, soil coverage allows improved microbiological conditions and enables a favorable environment for superficial root growth (SÁ et al., 2010); and, as pulse irrigation provides water in greater freque ncy within this layer, it is likely to happen yield enhancement.

WARNER, HOFFMAN and WILHOIT (2009), when comparing continuous and pulse drippings, also certified that the second was able to reduce water use in about $40 \%$, without affecting tomato quality and production.

The variance analysis summary of water-use efficiency for commercial and total yields is found in Table 4. Through these findings, it is noteworthy mention that the applied water depths, soil coverage, and the interaction between irrigation depths and mulching affected significantly $(\mathrm{p}<0.01)$ water- use efficiency. 
TABLE 4. Variance analysis summary of water-use efficiency for American crisphead lettuce commercial (WUE CY) and total (WUE TY) yields, with and without plastic mulching, and under effect of different irrigation water depths through pulse and continuous drip irrigation.

\begin{tabular}{lccc}
\hline \multirow{2}{*}{ Variation Causes } & \multirow{2}{*}{ DF } & \multicolumn{2}{c}{ Average square } \\
\cline { 3 - 4 } & & WUE CY & WUE TY \\
\hline Blocks & 2 & $0.35^{\mathrm{ns}}$ & $4.95^{\mathrm{ns}}$ \\
Depths (L) & 3 & $224.12^{* *}$ & $438.29^{* *}$ \\
Coverage (C) & 1 & $450.06^{* *}$ & $672.04^{* *}$ \\
L x C & 3 & $125.43^{* *}$ & $230.64^{* *}$ \\
Residue & 14 & 2.45 & 5.82 \\
VC $(\%)$ & & 5.97 & 6.43 \\
General Average & & 26.21 & 37.52 \\
\hline
\end{tabular}

Significant at $1 \%\left({ }^{* * *}\right)$ of probability; $\left({ }^{\mathrm{ns}}\right)$ not significant by $\mathrm{F}$ test

Table 5 demonstrates the average values of water-use efficiency at harvesting, considering different water depths applied continuously (control) and by pulses in cultivations with and without soil coverage use.

TABLE 5. Water-use efficiency (WUE) for American crisphead lettuce commercial and total yields, regarding factors interaction (coverage $\mathrm{x}$ irrigation).

\begin{tabular}{|c|c|c|c|c|c|}
\hline \multirow[t]{2}{*}{$\begin{array}{l}\text { Treatments } \\
\left(\% \mathrm{ET}_{\mathrm{C}}\right)\end{array}$} & \multirow[t]{2}{*}{$\begin{array}{c}\text { Depth } \\
(\mathrm{mm})\end{array}$} & \multicolumn{2}{|c|}{$\begin{array}{c}\text { WUE } \\
\text { Commercial Yield } \\
\left(\mathrm{kg} \mathrm{m}^{-3}\right)\end{array}$} & \multicolumn{2}{|c|}{$\begin{array}{c}\text { WUE } \\
\text { Total Yield } \\
\left(\mathrm{kg} \mathrm{m}^{-3}\right)\end{array}$} \\
\hline & & Without coverage & With coverage & Without coverage & With c \\
\hline 50-Pulses & 89.66 & $22.21 \mathrm{Bb}$ & $44.15 \mathrm{Aa}$ & $34.27 \mathrm{ABb}$ & $62.10 \mathrm{Aa}$ \\
\hline 75-Pulses & 120.49 & $26.39 \mathrm{Ab}$ & $32.59 \mathrm{Ba}$ & $37.47 \mathrm{Ab}$ & $45.03 \mathrm{Ba}$ \\
\hline 100-Pulses & 151.32 & $18.59 \mathrm{Bb}$ & $24.09 \mathrm{Ca}$ & $27.86 \mathrm{Cb}$ & $33.51 \mathrm{Ca}$ \\
\hline 100-Continuous & 151.32 & $20.32 \mathrm{Ba}$ & $21.34 \mathrm{Ca}$ & $30.07 \mathrm{BCa}$ & $30.97 \mathrm{Ca}$ \\
\hline
\end{tabular}

* Averages followed by the same letter do not differ statistically among themselves, upper case in column and lower case in line, by the Tukey test at $5 \%$ of probability.

It is noted that, without mulching, the treatment that obtained the best result, in terms of water-use efficiency, for commercial as well as total yield, was the one with $75 \%$ of ETc applied through dripping by pulses. With coverage use, the greatest water-use efficiency (44.15 and 62.10 $\mathrm{kg} \mathrm{m}^{-3}$, commercial and total yield, respectively) was obtained in treatment that $50 \%$ of ETc was applied via drip irrigation by pulses. It was also verified that as irrigation depths increased, there was a drop in water-use efficiency. LIMA JÚNIOR et al. (2010), who noticed that WUE decreased with the increment in applied depth, observed a similar performance in lettuce.

LIMA JÚNIOR et al. (2010), investigating the same cultivar of American crisphead lettuce, using continuous irrigation, observed that uncovered soil reached the maximum value of water-use efficiency of $56.31 \mathrm{~kg} \mathrm{~m}^{-3}$, with application of water depth of $74.53 \mathrm{~mm}$. Also studying the same cultivar, GEISENHOFF (2008) reported that mulching obtained the maximum value of WUE of $47.44 \mathrm{~kg} \mathrm{~m}^{-3}$ for tension of water in soil of $50.3 \mathrm{kPa}$.

It is worth mentioning that the best WUE can present a production lower than commercial standard. However, as observed, the interaction of drip irrigation by pulses with coverage resulted in greater production and, consequently, greater water-use efficiency, differently from the studies cited above. 


\section{CONCLUSIONS}

American crisphead lettuce irrigation via dripping by pulses enabled $25 \%$ of water savings in treatment without plastic mulching and $50 \%$ of water savings in treatments with plastic mulching, both of which has resulted in increased water-use efficiency.

\section{REFERENCES}

ABDELRAOUF, R. E.; ABOU-HUSSEIN, S. D.; REFAIE, K.; EL-METWALLY, I. M. Effect of pulse irrigation on clogging emitters, application efficiency and water productivity of potato crop under organic agriculture conditions. Australian Journal of Basic and Applied Sciences, Amman, v.6, n.3, p.807-816, 2012.

ALMEIDA, D.; KLAUBERG FILHO, O.; FELIPE, A. F.; ALMEIDA, H. C. Carbono, nitrogênio e fósforo microbiano do solo sob diferentes coberturas em pomar de produção orgânica de maçã no sul do Brasil. Bragantia, Campinas, v.68, n.4, p.1069-1077, 2009.

ASSOULINE, S.; MÖLLER, M.; COHEN, S.; BEM-HUR, M.; GRAVA, A.; NARKIS, K.; SILBER, A. Soil-plant system response to pulsed drip irrigation and salinity: bell pepper case study. Soil Science Society of Ame rica Journal, Madison, v.70, p.1556-1568, 2006.

BANDEIRA, G. R. L.; PINTO. H. C. S.; MAGAlHÃES, P. S.; ARAGÃO, C. A.; QUEIROZ, S. O.; SOUZA, E. R.; SEIDO, S. L. Manejo de irrigação para cultivo de alface em ambiente protegido. Horticultura B rasileira, Brasília, v.29, n.2, p.237-241, jun. 2011.

BAKEER, G. A. A.; EL-EBABI, F. G.; EL-SAIDI, M. T.; ABDELGHANY, A. Effect of pulse drip irrigation on yield and water use efficiency of potato crop under orga nic agriculture in sandy soils. Misr Society of Agricultural Engineering, Cairo, v.26, n.2, p.736-765, 2009.

DANTAS, A. A. A.; CARVALHO, L. G.; FERREIRA, E. Classificação e tendências climáticas em Lavras, MG. Ciência e Agrotecnologia, Lavras, v.31, n.6, p.1862-1866, nov./dez. 2007.

FERREIRA, D. F. SISVAR: um programa para análises e ensino de estatística. Revista Symposium, Lavras, v.6, p.36-41, 2008.

GEISENHOFF, L. O. Produção de alface ame ricana utilizando mulching dupla face, sob diferentes tensões de água no solo. 2008. Dissertação (Mestrado em Engenharia Agrícola) Universidade Federal de Lavras, Lavras, 2008.

GOMES, L. A. A.; SILVA, E. C.; FAQUIN, V. Recomendações de adubação para cultivos em ambiente protegido. In: RIBEIRO, A. C.; GUIMARÃES, P. T. G.; ALVAREZ, V. H. (Ed.).

Recomendações para o uso de corretivos e fertilizantes em Minas Gerais : $5^{\text {a }}$ aproximação. Viçosa, UFV, 1999.

GONÇALVES, A. O.; FAGNANI, M. A.; PERES, J. G. Efeitos da cobertura do solo com filme de polietileno azul no consumo de água da cultura da alface cultivada em estufa. Engenharia Agrícola, Jaboticabal, v.25, n.3, p.622-631, 2005.

KELLER, J.; KARMELI, D. Trickle irrigation design. Glendora: Rain Bird Sprinkler Manufacturing, 1975. 133p.

LIMA JÚNIOR, J. A.; PEREIRA, G. M.; GEISEN HOFF, L. O.; COSTA, G. G.; VILAS BOAS, R. C.; YURI, J. E. Efeito da irrigação sobre o rendimento produtivo da alface americana, em cultivo protegido. Revista Brasileira de Engenharia Agrícola e Ambiental, Campina Grande, v.14, n.8, p.797- 803, 2010.

MAROUELLI, W. A.; SILVA, W. L. C.; SILVA, H. R. Manejo da irrigação em hortaliças. 5. ed. Brasília: EMBRAPA, 1996. 72p. 
RESENDE, G. M.; ALVARENGA, M. A. R.; YURI, J. E.; SOUZA, J.; MOTA, J. H.;

CARVALHO, J. G.; RODRIGUES JÚNIOR, J. C. Rendimento e teores de macronutrientes em alface tipo americana em função de doses de nitrogênio e molibdênio em cultivo de verão. Ciência e Agrotecnologia, Lavras, v. 33, n. 1, p. 153-163, 2009.

SÁ, J. C. M.; FERREIRA, A. O.; BRIEDIS, C.; VIEIRA, A. M.; FIGUEIREDO, A. G.

Crescimento radicular, extração de nutrientes e produção de grãos de genótipos de milho em diferentes quantidades de palha de aveia-preta em plantio direto. Revista Brasileira de Ciência do Solo, Viçosa, MG, v.34, n.4, p.1207-1216, 2010.

SALA, F. C.; COSTA, C. P. Retrospectiva e tendência da alfacicultura brasileira. Horticultura Brasileira, Vitória da Conquista, v.30, n.2, p.187-194, 2012.

SANTANA, C. V. S.; ALMEIDA, A. C.; TURCO, S. H. N. Produção de alface roxa em ambientes sombreados na região do Submédio São Francisco - BA. Revista Verde de Agroecologia e Desenvolvimento Sustentável, Campina Grande, v.4, n.3, p.1-6, 2009.

WARNER, R.; HOFFMAN, O.; WILHOIT, J. The effects of pulsing drip irrigation on tomato yield and quality in kentucky. 2009. Disponível em: <http: //www.ca.uky.edu/agc/ pubs/pr/pr603/pr603.pdf>. Acesso em: 9 maio 2012.

ZIN EL-ABEDIN, T.K. Effect of pulse drip irrigation on soil moisture distribution and maize production in clay soil. 2006. Disponível em: <http:// www.mjae.eg.net/pdf/2006/nov/19.pdf>. Acesso em: 21 set. 2012.

ZRIBI, W.; FACI, J. M.; ARAGÜES, R. Efectos del acolchado sobre la humedad, temperatura, estructura y salinidad de suelos agrícolas. ITEA, Zaragoza, v.107, n.2, p.148-162, 2011. 